\title{
Suffolk Sheep
}

National Cancer Institute

\section{Source}

National Cancer Institute. Suffolk Sheep. NCI Thesaurus. Code C106572.

A strain of sheep orig inally derived in England in the 1880s from a cross between a

Southdown ram and a Norfolk Horned ewe. The Suffolk sheep has a white-colored body, black face and legs, and has a wool type of medium. 